\title{
An Overwiev of the Neural Crest Cells and Tumor Metastasis
}

Nihan BAYINDIR, Mukaddes EŞREFOĞLU

Department of Histology and Embryology, Bezmialem Vakıf University School of Medicine, İstanbul, Turkey

\section{ABSTRACT}

Neural crest cells (NCCs) derived from neuroectoderm are multipotential cells. NCCs leave the neuroepithelium and migrate to various tissues by epithelial-mesenchymal transition. In this areas NCCs differentiate to variety of cells including melanocytes, glia cells, chromaffin cells. Cancer is a complex process which involves a dinamic interaction between tumor cells and surrounding micrenvironment. Cancer cells similar to neural crest cells leave their own environments and metastasize into a different tissue. The development of the neural crest and that of cancer progression share paralel morphological and molecular characteristics. Many signalling pathway and transcription factors are mutual for both processes. To investigate neural crest developmental mechanisms will provide a better understanding for cancer development, progression and metastasis.

Keywords: Epithelial-mesencymal transition, cancer, metastasis, neural crest

\section{Introduction}

Neural crest (NC) cells have the ability for high proliferation and differentiation. Neural folds form in the dorsal part of the embryo during the third week of embryonic development. While the neural folds fuse together to form the neural tube, cells located at the lateral border of the neuroectoderm begin to migrate to the underlying mesoderm, leaving the site where they are located. These cells are called NC cells (1). By leaving this area and migrating to a new location, NC cells function by differentiating into cells of various tissues. Thus, they differentiate into various cells such as glial cells, endocrine cells, pigment cells, odontoblasts, parafollicular cells, and adrenal gland cells (2). They also contribute to the formation of bones, cartilages, and connective tissues of the head and neck as well as to the formation of blood vessels (3). The phenotype of NC cells is epithelial. To leave the ectoderm of the area where they arise from, they must acquire mesenchymal cell properties by losing their epithelial properties (4). Therefore, they lose intercellular junctions and cell polarity; the cell skeleton is then rearranged and they gain the ability to move. Cells that differentiate in this manner begin to migrate from their original location. Similarly, during metastasis, tumor cells mimic the migration of NC cells during the early embryonic period. After epithelial tumor cells acquire mesenchymal properties, they migrate to various areas by leaving the tissues they arise from and reproduce at the new location. This is called metastasis.

These similarities between the migration of NC cells and cancer metastasis make NC cells an excellent model for the better understanding of the molecular mechanism underlying tumor cell metastasis. Several signaling pathways and transcription factors have been shown to act similarly at a molecular level in both events (5). The migration of both cell types occurs under the control of various positive and negative regulatory factors, such as sdf1, semaphorin, ephrin/Eph, and slit (6-9).

\section{Epithelial-Mesenchymal Transition}

The migration of NC cells and metastasis of tumor cells are multi-stage complex processes that require epithelialmesenchymal transition (EMT). In both cases, the first step is the separation of the cells from the epithelial tissue. While epithelial cells are intracellularly attached to each other via tight junctions, mesenchymal cells are more 
dynamic and they are moving cells. In the EMT process, intercellular junctional complexes disappear, apicobasal cell polarity becomes uncertain, and cellular skeletal elements are rearranged (10).

\subsection{Intercellular Junctions}

In the epithelial tissue, cells get attached to each other via binding complexes such as zonula occludens, zonula adherens, and macula adherens to form a durable tissue. While certain occludin and claudin transmembrane proteins serve in zonula occludens-type junctions, proteins from the immunoglobulin family and transmembrane proteins from the cadherin group serve in the zonula adherenstype junctions (11). Immediately before the migration of NC cells, the expression of the molecules forming tight junctions changes. Before the migration process begins, the expressions of occludin and claudin are repressed by the transcriptional factor Snail. By triggering EMT, Snail functions in the acquisition of the mesenchymal phenotype by epithelial cells (12).

It has been shown that when cells leave each other, cell migration and invasion begins; thus, metastatic tumors form in humans with the loss of tight junction structures in various cancer types (13). A decrease in the expressions of occludin and zonula occludens- 1 is associated with the metastasis of liver, ovary, endometrium, and breast cancers (14).

In addition to changes in the expressions of the proteins occludin and claudin, changes are also observed in the expression of E-cadherin proteins among $\mathrm{NC}$ cells before migration. As in E-cadherin first and then in $\mathrm{N}$-cadherin, the expressions of other cadherin molecules begin to decrease in the cell membrane. This decline is the first step for NC cells to leave the other ectodermal cells and become specialized (15). Indeed, $\mathrm{N}$-cadherin is a molecule that blocks the delamination of NC cells by preserving intracellular junctions (16). In the EMT process, A disintegrin and metalloproteinase domaincontaining protein 10 (ADAM10), a member of the zinc protease superfamily, destroys and eliminates $\mathrm{N}$-cadherin (17). After the decline of E-cadherin and N-cadherin, NC cells begin to express the mesenchymal cadherin-7 and cadherin-11 (18). The initiation of the expression of the mesenchymal cadherins is very important for the proliferation of cells in the tissues, following the deformation of junctions among cells and their migration (19).

As a negative regulator of the $\beta$-catenin signaling pathway, E-cadherin also plays an important role in the inhibition of tumor cell metastasis (20). E-cadherin expression has been shown to inhibit metastasis in pancreatic, breast, bladder, and lung cancers (21). In other words, the loss of E-cadherin is an important marker of EMT in tumor progression (22). The expressions of $\mathrm{N}$-cadherin and cadherin- 6 also immediately decrease before the migration of metastatic cancer cells (23).

\subsection{Basement Membrane}

The barriers surrounding the epithelium should be surpassed for the cells to be released and to initiate migration. The basement membrane beneath the epithelium mainly consists of type IV collagen, fibronectin, and laminin molecules. NC cells must destroy the basement membrane to complete the EMT process and leave the neuroepithelium. They synthesize the matrix metalloproteinase (MMP) molecules at this stage (24). When NC cells begin to migrate, the integrity of basement membrane is disrupted with the increase of MMP2, -8 , and -9 expressions (25). Duong et al. (26) demonstrated that MMP-2 inhibition blocks EMT.

ADAM family is a member of metalloproteinases. The cranial NC cells in Xenopus increase ADAM9 and 13 expressions to disrupt the structure of the extracellular matrix. Members of the ADAM family also trigger cell proliferation and angiogenesis by inhibiting apoptosis, thus causing the spread of tumors (27).

Tumor cells reach the vessels by secreting MMP and ADAM molecules and metastasize by passing the endothelial basement membrane (28). In glioblastoma and neuroblastoma cancer cells, MMP-2, -9, and ADAM-10 expressions increase (29). MMP-2, -9, and -14 have been shown to have an inducing role in the processes of tumor invasion and angiogenesis in mouse (30).

\subsection{Cell Polarity}

The loss of intracellular junctions and basement membrane integrity disrupts cell polarity, which is characteristic for epithelial cells. The disruption of cell polarity also indicates EMT, and it is one of the early indicators of tumor growth (31).

Cell polarity is maintained at a molecular level by various polarity complexes. Crumb (Crb) protein complex in the apical cell membrane stabilizes the placement of the Par protein complex located in tight junctions. The decrease in Crb3 protein expression in renal epithelial cells has been demonstrated to increase cell movements by influencing junctional complexes to trigger tumorigenic potential and induce metastasis (32). Crb3 protein expression needs to be suppressed for the formation of tumor in mouse epithelial cells. A decrease in Crb3 expression is associated with an increase in vimentin expression in cells and a decrease in E-cadherin expression, which means that the cell gains a mesenchymal characteristic (33). These data indicate that Crb3 has significant roles in the protection of apicobasal polarity and tight junctions and in the suppression of migration and metastasis. The polarity in the basolateral face is under the control of the Scribble protein complex. The expression of the Scribble complex has been shown to decrease in cervical cancers, colon cancers, and melanoma (34). Through the disruption of cell polarity, Snail and zinc finger E-box binding homeobox-1 (Zeb-1) molecules trigger EMT by suppressing the activation of Crumb genes (35). The 
Snail gene has also been shown to protect cancer cells from death by suppressing apoptosis (36). It has been shown in the studies conducted in Xenopus that the expressions of Snail, Zeb1, and Zeb2 molecules are required for the development and migration of NC cells (37).

\section{Migration Process}

After passing the basement membrane, NC cells which have gained the ability to move enter the extracellular matrix. A number of molecules are released from the migrating cells to pass the microenvironment here. $\mathrm{NC}$ cells bind to fibronectin by increasing the expressions of laminin, $\alpha 4 \beta 1, \alpha 5 \beta 1$, and $\alpha 1 \beta 1$ integrins. The inhibition of $\beta 1$ subunit has been shown to be associated with the progression and recurrence of breast cancer (38).

When NC cells start to migrate, activating and/or inhibiting signal molecules are secreted from the surrounding tissues. $\mathrm{NC}$ cells are enabled to reach these areas by the secretion of positive regulators from the target organs. Positive regulators are growth factors such as FGF, VEGF, and PDGF and various molecules such as chemokine SDF-1. Increase in FGF and PDGF levels triggers EMT in many cancers (39).

Some negative regulatory molecules are engaged to prevent the migration of $\mathrm{NC}$ cells to the organs where these cells should not settle. There are two main negative regulatory molecule-ligand complexes. These are ephrin and Eph ligands as well as class 3 semaphorins and neurophilin/ plexin receptors (40). By being expressed in tissues where the NC cells normally should not migrate to, these molecules prevent NC cells from settling at these places (41). Eph and neurophilin also prevent the migration of NC cells by constricting their extensions. The loss of Eph/ Ephrin and neurophilin/semaphorin expressions results in ectopic migration of NC cells (42). Loss of the expressions of ephrin and semaphorin has been shown in the studies of some cancers such as lung and breast cancers in humans, thereby indicating that these molecules have important roles in tumor progression and metastasis (43).

Apart from the positive and negative regulatory molecules, Wnt (44) and p53 (45) molecules play a role in the migration and differentiation of NC and tumor cells by triggering EMT. The decrease in the tumor suppressor gene $\mathrm{p} 53$ in cranial $\mathrm{NC}$ cells induces NC cells to acquire invasive phenotype by triggering EMT (45).

The migration process stops when NC cells reach the target organs and contact with other cells (contact inhibition). Wnt/planar cell polarity signaling pathway triggers contact inhibition activating RhoA in contact points with the cell next to the NC cell (44). Cancer cells return to epithelial phenotype by undergoing a mesenchymal-epithelial transition in the area where they metastasize. Thus, settling in these areas, they rapidly reproduce. Cancer cells returning to epithelial phenotype have been observed to be more durable than those of mesenchymal origin (46). When cancer cells are blocked to return to epithelial phenotype in areas where they metastasize, the chances of their survival can be reduced.

\section{Neural Crest Microenvironment and Cancer}

The migration, proliferation, and differentiation of NC cells are required for a normal embryonic development. Mintz and Illmensee (47) suggested that the microenvironment in mouse blastocyst stage can suppress the metastatic properties of cancer cells. Indeed, tumorigenic phenotype of cancer cells deteriorates in embryonic micro-environment. It was observed that human melanoma cells did not create tumors when injected through the premigratory period NC cells of chicken embryos; on the contrary, they were observed to migrate to the pharyngeal arch, dorsal root ganglia, and sympathetic ganglia similar to NC cells (48). Similar to NC cells, C8161 melanoma cells injected into chicken embryo exhibit an extended cell morphology that establishes contact with the neighboring cells in the NC microenvironment in the region (49). On the contrary, when injected into a microenvironment different from that of NC cells, B19 mouse melanoma cells were observed to form tumors in these areas (50). This difference indicates that cancer cells exhibit an extraordinary (nontumorigenic and non-metastatic) phenotype only in the NC microenvironment.

\section{Conclusion}

Neural crest and tumor cells undergo EMT. After it was understood that the molecules having a role in the migration and differentiation of the NC cells also play an effective role in the migration of cancer cells, it was believed that important data related to the formation, progression, and metastasis of cancer could be obtained by investigating in detail the behavioral patterns of NC cells. The discovery of mechanisms underlying the loss of metastatic cell phenotype by cancer cells around the $\mathrm{NC}$ microenvironment will enable the development of reprogramming strategies related to the microenvironment to prevent metastasis.

Peer-review: Externally peer-reviewed.

Author Contributions: Concept - B.N.; Design - B.N.; E.M.Supervision E.M.; Literature Review - B.N.; Writing - B.N.; Critical Review - E.M

Conflict of Interest: No conflict of interest was declared by the authors.

Financial Disclosure: The authors declared that this study has received no financial support.

\section{References}

1. Sadler TW. Langman Medikal Embriyoloji (A.C. Başaklar Çev.). Ankara: Palme Yayınları; 2003.

2. Hall B. The Neural Crest and Neural Crest Cells in Vertebrate Development and Evolution. 2nd ed. New York: Springer; 2008.

3. Etchevers HC, Vincent C, Le Douarin NM, Couly GF. The cephalic neural crest provides pericytes and smooth muscle cells to all blood vessels of the face and forebrain. Development 2001; 28: 1059-68. 
4. Acloque H, Adams MS, Fishwick K, Bronner-Fraser M, Nieto MA. Epithelial_mesenchymal transitions: the importance of changing cell state in development and disease. J Clin Invest 2009; 119: 1438-49. [CrossRef]

5. Thiery JP, Acloque H, Huang RY, Nieto MA. Epithelial-mesenchymal transitions in development and disease. Cell 2009; 139: 871-90. [CrossRef]

6. Theveneau E, Marchant L, Kuriyama S, Gull M, Moepps B, Parsons M, Mayor R. Collective chemotaxis requires contact-dependent cell polarity. Dev Cell 2010; 19: 39-53. [CrossRef]

7. Gammill LS, Gonzalez C, Gu C, Bronner-Fraser M. Guidance of trunk neural crest migration requires neuropilin $2 /$ semaphorin $3 \mathrm{~F}$ signaling. Development 2006; 133: 99-106. [CrossRef]

8. De Bellard ME, Ching W, Gossler A, Bronner- Fraser M. Disruption of segmental neural crest migration and ephrin expression in delta-1 null mice. Dev Biol 2002; 249: 121-30. [CrossRef]

9. De Bellard ME, Rao Y, Bronner-Fraser M. Dual function of Slit2 in repulsion and enhanced migration of trunk, but not vagal, neural crest cells. J Cell Biol 2003; 162: 269-79. [CrossRef]

10. Powell DR, O’Brien JH, Ford HL, Artinger K.B. Neural Crest Cells and Cancer: Insights into Tumor Progression. In: Trainor PA editör. Neural Crest Cells. USA: Elsevier; 2014. s. 335-57.

11. Eşrefoğlu M. Genel Histoloji. Malatya: Medipress; 2009.

12. Martinez-Estrada OM, Culleres A, Soriano FX, Peinado H, Bolos V, Martinez FO, et al. The transcription factors Slug and Snail act as repressors of Claudin-1 expression in epithelial cells. Biochem J 2006; 394: 449-57. [CrossRef]

13. Fazakas C, Wilhelm I, Nagyoszi P, Farkas AE, Hasko J, Molnar J, Bauer H, Bauer HC, Ayaydin F, Dung NTK, Siklos L, Krizbai IA. Transmigration of melanoma cells through the blood-brain barrier: role of endothelial tight junctions and melanoma-released serine proteases. PLoS One 2011; 6: e20758. [CrossRef]

14. Orban E, Szabo E, Lotz G, Kupcsulik P, Paska C, Schaff Z, et al. Different expression of occludin and ZO-1 in primary and metastatic liver tumors. Pathol Oncol Res 2008; 14: 299-306. [CrossRef]

15. Nakagawa S, Takeichi M. Neural crest cell-cell adhesion controlled by sequential and subpopulationspecific expression of novel cadherins. Development 1995; 121: 1321-32.

16. Shoval I, Ludwig A, Kalcheim C. Antagonistic roles of full-length $\mathrm{N}$-cadherin and its soluble BMP cleavage product in neural crest delamination. Development 2007; 134: 491-501. [CrossRef]

17. Reiss K, Maretzky T, Ludwig A, Tousseyn T, de Strooper B, Hartmann $\mathrm{D}$, et al. ADAM10 cleavage of $\mathrm{N}$-cadherin and regulation of cell-cell adhesion and beta-catenin nuclear signalling. EMBO J 2005; 24 : $742-$ 52. [CrossRef]

18. Chu YS, Eder O, Thomas WA, Simcha I, Pincet F, Ben-Ze'ev A, et al. Prototypical type I Ecadherin and type II cadherin-7 mediate very distinct adhesiveness through their extracellular domains. J Biol Chem 2006; 281: 2901-10. [CrossRef]

19. Koehler A, Schlupf J, Schneider M, Kraft B, Winter C, Kashef J. Loss of Xenopus cadherin-11 leads to increased Wnt/bcatenin signaling and up-regulation of target genes c-myc and cyclin D1 in neural crest. Dev Biol 2013; 383: 132-45. [CrossRef]

20. Schmalhofer O, Brabletz S, Brabletz T. E-cadherin, beta-catenin, and ZEB1 in malignant progression of cancer. Cancer Metastasis Rev 2009; 28: 151-66. [CrossRef]

21. Perl AK, Wilgenbus P, Dahl U, Semb H, Christofori G. A causal role for E-cadherin in the transition from adenoma to carcinoma. Nature 1998; 392: 190-3. [CrossRef]

22. Yang J, Weinberg RA. Epithelial_mesenchymal transition: at the crossroads of development and tumor metastasis. Dev Cell 2008; 14: 81829. [CrossRef]

23. Nieman MT, Prudoff RS, Johnson KR, Wheelock MJ. $\mathrm{N}$-cadherin promotes motility in human breast cancer cells regardless of their E-cadherin expression. J Cell Biol 1999; 147: 631-44. [CrossRef]
24. Innes PB. The ultrastructure of early cephalic neural crest cell migration in the mouse. Anat Embryol 1985; 172: 33-8. [CrossRef]

25. Giambernardi TA, Sakaguchi AY, Gluhak J, Pavlin D, Troyer DA, Das G, et al. Neutrophil collagenase (MMP-8) is expressed during early development in neural crest cells as well as in adult melanoma cells. Matrix Biol 2001; 20: 577-87. [CrossRef]

26. Duong TD, Erickson CA. MMP2 plays an essential role in producing epithelial-mesenchymal transformations in the avian embryo. Dev Dyn 2004; 229: 42-53. [CrossRef]

27. Rocks N, Paulissen G, El Hour M, Quesada F, Crahay C, GuedersM, et al. Emerging roles of ADAM and ADAMTS metalloproteinases in cancer. Biochimie 2008; 90: 369-79. [CrossRef]

28. Nair SA, Jagadeeshan S, Indu R, Sudhakaran PR, Pillai MR. How intact is the basement membrane? Role of MMPs. Adv Exp Med Biol 2012; 749: 215-32. [CrossRef]

29. Hofmann UB, Houben R, Brocker EB, Becker JC. Role of matrix metalloproteinases in melanoma cell invasion. Biochimie 2005; 87: 30714. [CrossRef]

30. Masson V, de la Ballina LR, Munaut C, Wielockx B, Jost M, Maillard C, et al. Contribution of host MMP-2 and MMP- 9 to promote tumor vascularization and invasion of malignant keratinocytes. Faseb J 2005; 19: 234-6.

31. Royer C, Lu X. Epithelial cell polarity: a major gatekeeper against cancer? Cell Death Differ 2011; 18: 1470-7. [CrossRef]

32. Karp CM, Tan TT, Mathew R, Nelson D, Mukherjee C, Degenhardt $\mathrm{K}$, et al. Role of the polarity determinant crumbs in suppressing mammalian epithelial tumor progression. Cancer Res 2008; 68: 4105-15. [CrossRef]

33. Regala RP, Weems C, Jamieson L, Khoor A, Edell ES, Lohse CM, et al. Atypical protein kinase $\mathrm{C}$ iota is an oncogene in human non-small cell lung cancer. Cancer Res 2005; 65: 8905-11. [CrossRef]

34. Nakagawa S, Yano T, Nakagawa K, Takizawa S, Suzuki Y, Yasugi T, et al. Analysis of the expression and localisation of a LAP protein, human scribble, in the normal and neoplastic epithelium of uterine cervix. Br J Cancer 2004; 90: 194-9. [CrossRef]

35. Ellenbroek SI, Iden S, Collard JG. Cell polarity proteins and cancer. Semin Cancer Biol 2012; 22: 208-15. [CrossRef]

36. Vega S, Morales AV, Ocana OH, Valdes F, Fabregat I, Nieto MA. Snail blocks the cell cycle and confers resistance to cell death. Genes Dev 2004; 18: 1131-43. [CrossRef]

37. LaBonne C, Fraser MB. Snail-Related Transcriptional Repressors AreRequired in Xenopus for both the Induction of the Neural Crest and Its Subsequent Migration. Developmental Biology 2000; 221: 195-205. [CrossRef]

38. Barkan D, Chambers AF. Beta1-integrin: a potential therapeutic target in the battle against cancer recurrence. Clin Cancer Res 2011; 17: 7219-23. [CrossRef]

39. Kono SA, Heasley LE, Doebele RC, Camidge DR. Adding to the mix: fibroblast growth factor and platelet-derived growth factor receptor pathways as targets in non-small cell lung cancer. Curr Cancer Drug Targets 2012; 12: 107-23 [CrossRef]

40. Santiago A, Erickson CA. Ephrin-B ligands play a dual role in the control of neural crest cell migration. Development 2002; 129: 3621-32.

41. Krull CE, Lansford R, Gale NW, Collazo A, Marcelle C, Yancopoulos GD, Fraser SE, Bronner-Fraser M. Interactions of Eph-related receptors and ligands confer rostrocaudal pattern to trunk neural crest migration. Curr Biol 1997; 7: 571-80. [CrossRef]

42. Smith A, Robinson V, Patel K, Wilkinson DG. The EphA4 and EphB1 receptor tyrosine kinases and ephrin-B2 ligand regulate targeted migration of branchial neural crest cells. Curr Biol 1997; 7: 561-70. [CrossRef]

43. Harburg GC, Hinck L. Navigating breast cancer: axon guidance molecules as breast cancer tumor suppressors and oncogenes. J Mammary Gland Biol Neoplasia 2011; 16: 257-70. [CrossRef]

44. Polakis P. Wnt signaling in cancer. Cold Spring Harb Perspect Biol 2012; 4: 5. [CrossRef] 
45. Rinon A, Molchadsky A, Nathan E, Yovel G, Rotter V, Sarig R, Tzahor E. p53 coordinates cranial neural crest cell growth and epithelial-mesenchymal transition/delamination processes. Development 2011; 138: 1827-38. [CrossRef]

46. Polyak K, Weinberg RA. Transitions between epithelial and mesenchymal states: acquisition of malignant and stem cell traits. Nat Rev Cancer 2009; 9: 265-73. [CrossRef]

47. Mintz, B. \& Illmensee, K. Normal genetically mosaic mice produced from malignant teratocarcinoma cells. Proc Natl Acad Sci USA 1975; 72: 3585-9. [CrossRef]

48. Kulesa PM, Kasemeier-Kulesa JC, Teddy JM, Margaryan NV, Seftor EA, Seftor RE, Hendrix MJ. Reprogramming metastatic melanoma cells to assume a neural crest-cell like phenotype in an embryonic microenvironment. PNAS 2006; 103: 3752-7. [CrossRef]

49. Wyckoff JB, Wang Y, Lin EY, Li JF, Goswami S, Stanley ER, Segall JE, Pollard JW, Condeelis J. Direct visualization of machrophage-assisted tumor cell intravasation in mammary tumors. Cancer Res 2007; 67: 2649-56. [CrossRef]

50. Oppitz M, Busch C, Schriek G, Metzger M, Just L, Drews U. Nonmalignant migration of B16 mouse melanoma cells in the neural crest and invasive growth in the eye cup of the chick embryo. Melanoma Res 2007; 17: 17-30. [CrossRef] 